\title{
Late Wisconsin History North of the Giants Range, Northern Minnesota, Inferred from Complex Stratigraphy ${ }^{1}$
}

\author{
SVANTE BJÖRCK \\ Department of Quaternary Geology, Lund University, Tornav 13, S-223, 63 Lund, Sweden, and Limnological \\ Research Center, Pillsbury Hall, University of Minnesota, Minneapolis, Minnesota 55455
}

Received September 26, 1988

\begin{abstract}
In an area north of the Giants Range in northeastern Minnesota the late Wisconsin glacial and extraglacial lithostratigraphy shows that, apart from one occurrence of red clayey till, the deposits can be related to the deglaciation of the Rainy Lobe, the margin of which retreated northward, leaving debris-rich ice behind. By a combination of pollen stratigraphy, lithostratigraphy, and chronostratigraphy of lake sediments in this area, together with multivariate numerical analyses of the data set, a "hiatus" stratigraphy was set up. Combined with the glacial and extraglacial stratigraphy, it shows that the area of Glacial Lake Norwood was possibly later filled with sediments, between masses of stagnant ice, following a damming of drainge in the south by the St. Louis Sublobe. The area was drained through the Embarrass channel when the St. Louis Sublobe retreated. Then followed the drainage of Lake Koochiching through the Embarrass channel. At ca. $10,200{ }^{14} \mathrm{C}$ yr B.P. the area apparently became free of stagnant ice as normal lake sedimentation began in all lakes studied. A lake-level rise is indicated ca. $1000 \mathrm{yr}$ later. Apart from a long-lasting phase of birch tundra parkland between ca. 12,000 (or 11,500 ?) and $10,600{ }^{14} \mathrm{C}$ yr B.P., the general pollen stratigraphy fits into the regional picture with a more or less undisturbed and gradual plant immigration from the time of the culmination of the St. Louis Sublobe. 1990 University of Washington.
\end{abstract}

\section{INTRODUCTION}

The complex late Wisconsin till stratigraphy in Minnesota has been interpreted in many different ways with respect to the spatial distribution of different ice lobes, their absolute and relative timing, and their driving mechanisms (e.g., climate, surges). In northeastern Minnesota three main late Wisconsin lobes are distinguished (Wright, 1969, 1972): the Superior Lobe which flowed from the northeast, the Rainy Lobe which flowed from the north-northeast, and the St. Louis Sublobe which flowed from the northwest. During the retreat of the Rainy Lobe large areas west of Lake Superior became free of active ice much earlier than areas to the south, west, and east. The late Wisconsin pollen stratigraphy of Weber Lake (Fries, 1962), situated in the eastern part of this region of early deglaciation

\footnotetext{
${ }^{1}$ Contribution 368, Limnological Research Center, University of Minnesota.
}

(WL in Fig. 1), shows no clear climatically induced vegetation changes despite the fact that the region should have been influenced by several different ice readvances after the retreat of the Rainy Lobe (Wright and Watts, 1969). This led Wright (1969, 1973; Wright and Watts, 1969) to discuss the possibility (1) that the two last Superior Lobe advances were glacier surges from the deep Lake Superior basin or (2) that changes in snow accumulation rather than reduction in marginal ablation led to ice advances.

Such interpretations of the glacial history of Minnesota, involving a progressive late Wisconsin climatic amelioration without reversals, were supported by the studies of Cushing (1967) and Birks (1976, 1981). Kylen Lake (KL in Fig. 1) and Lake of the Clouds (LC) show basically the same vegetational history as Weber Lake (Birks, 1981; Craig, 1972), and the interpretation was supported by principal-components analysis of the fossil pollen spectra for the three lakes (Birks, 1981). 


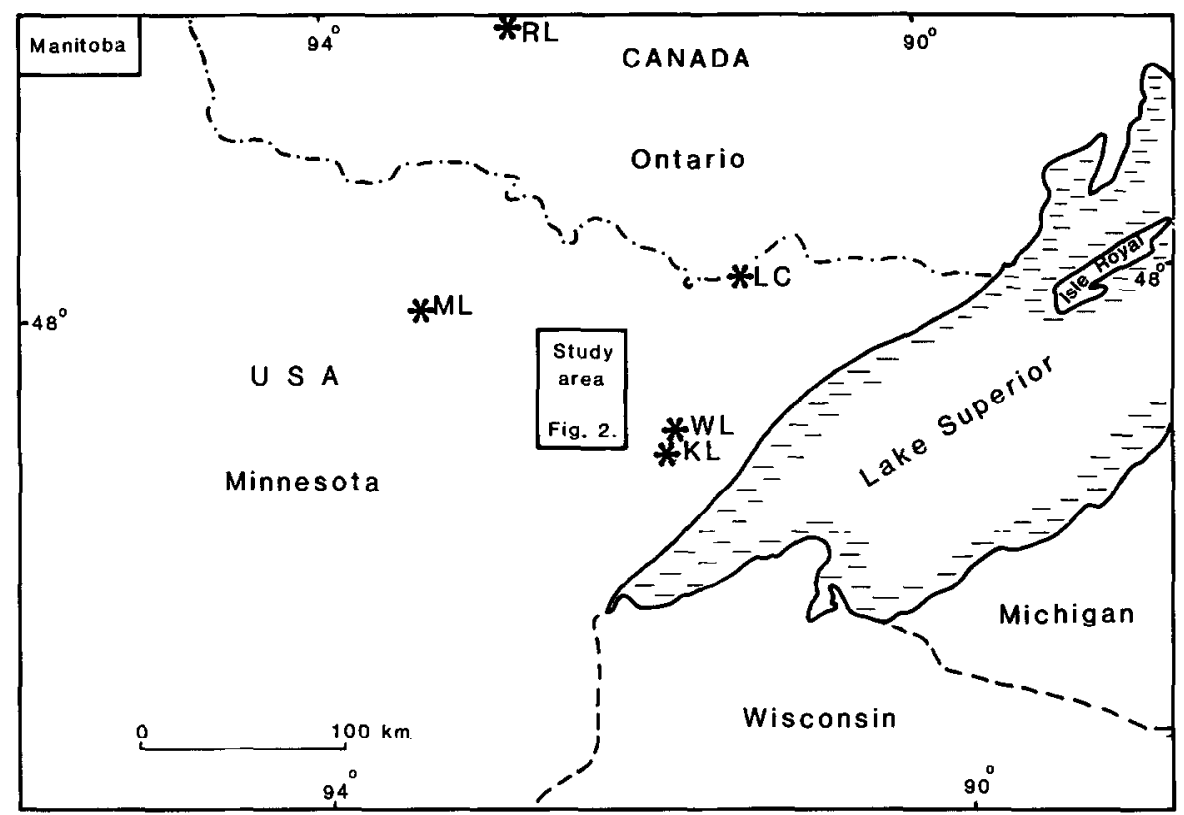

FIG. 1. Map of the Lake Superior region indicating the position of the study area, including the positions of other studied late Wisconsin sequences in northern Minnesota and western Ontario. RL, Rattle Lake (Björck, 1985); LC, Lake of the Clouds (Craig, 1972); ML, Myrtle Lake (Janssen, 1968); WL, Weber Lake (Fries, 1962); KL, Kylen Lake (Birks, 1981).

West of the Weber Lake-Kylen Lake area, the St. Louis Sublobe advanced from the northwest at the time of the final Superior Lobe readvance (Wright, 1972), or possibly slightly later (Clayton and Moran, 1982). This sublobe overrode Glacial Lakes Aitkin I and Upham I, incorporating reddish-brown lake sediments (originating from an earlier Superior Lobe advance) into its till (Wright, 1972). The distribution of this reddish till shows that the St. Louis Sublobe was divided into two sublobes (Winter, 1971) by the Giants Range, the granitic highland north the Mesabi Iron Range. One sublobe entered the northwestern part of the map area (Fig. 2), and the second was confined to the area south of the Giants Range, extending east of Aurora and probably into the southern part of the Embarrass channel (Winter, 1971). North of the Giants Range lay Glacial Lake Norwood (Winchell, 1901), which formed during the retreat of the Rainy Lobe (Winter, 1971). According to Clayton and Moran's
(1982) glacial chronology (Fig. 3), based only on dates of wood, the Rainy Lobe retreated north of the Giants Range ca. 14,000 yr B.P., and the St. Louis Sublobe reached its maximum position 11,700 yr B.P. This latter date, however, is older than the two radiocarbon dates of wood $(11,330 \pm 350$, W-827; $11,100 \pm 400$ yr B.P., W-1140) from the red clayey till in the Mariska mine west of Aurora, indicating that ice was also active at a slightly later time.

According to Hobbs (1983), the eastern arm of Glacial Lake Agassiz, called Lake Koochiching, drained by the Pike River through the Embarrass channel and into Lake Upham during Mizpah stage. The exact age of this stage is unknown, but it should have occurred sometime between 12,000 and 11,500 yr B.P. (Clayton, 1983), before the diversion of drainage to the Prairie River during the Gemmell stage ca. 11,500 yr B.P. (Clayton, 1983).

Thus, if the Rainy Lobe retreated far enough to form a deep lake (i.e., Glacial 


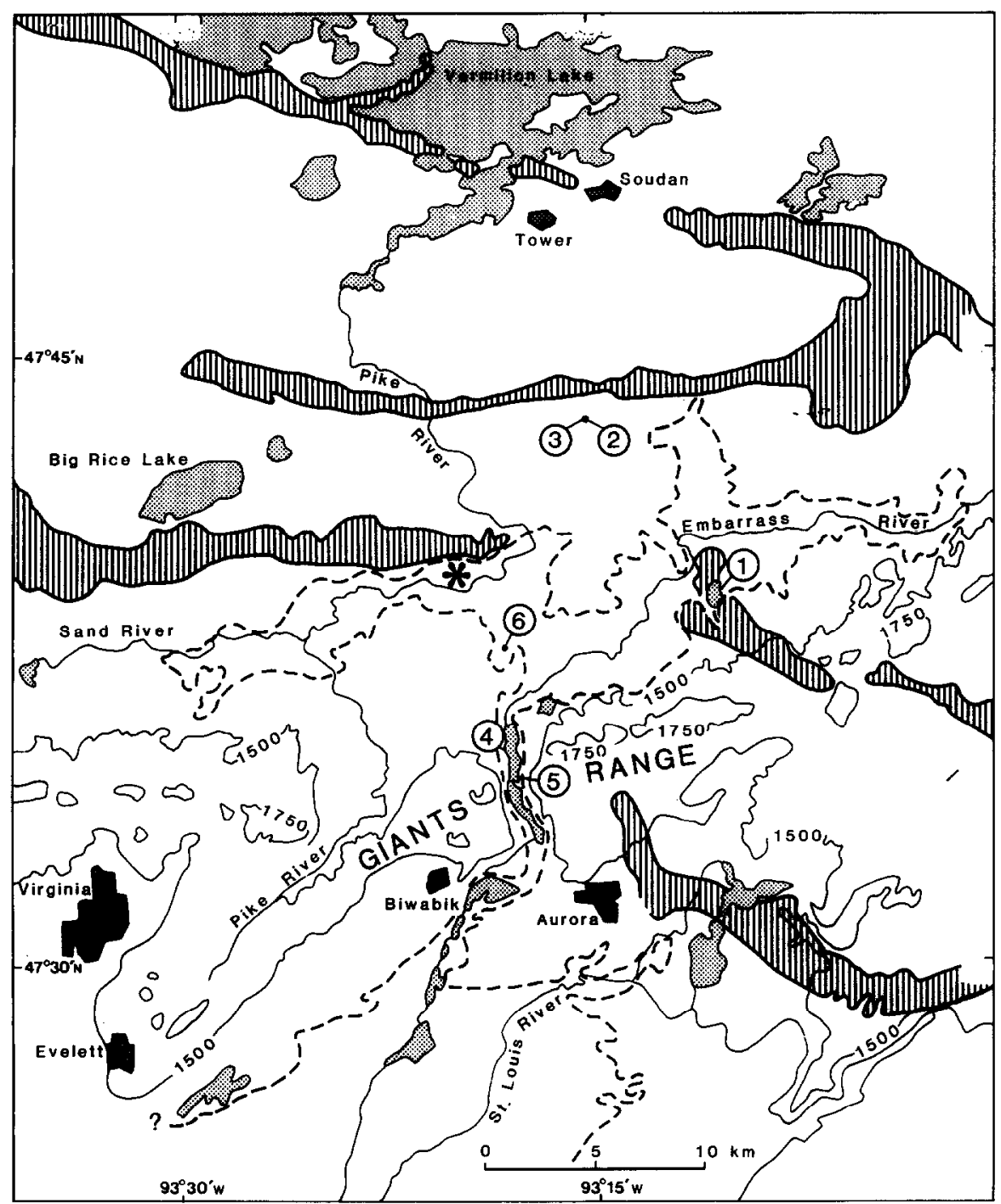

FIG. 2. Map of the framed area in Fig. 1. The lined areas correspond to the Vermillion Moraines. The dashed line north of the Giants Range marks the limit of the Glacial Lake Norwood sediments. The numbers refer to the lake sites studied $(1=$ Heikkilla Lake, 2 and $3=S$. Lempia Lake, 4 and 5 $=$ Sabin Lake, $6=$ Swamp Lake). The asterisk shows the position of the site with red clayey till. The 1500- and 1750-ft contour lines are shown as well as the larger lakes (light gray) and rivers and some of the towns (dark gray).

Lake Norwood), the area north of the Giants Range must have been free of stagnant ice immediately after deglaciation. Sediments in such a lake should date at least from the time of the St. Louis Sublobe advance west and south of the Giants Range and should record any climatic and vegetational changes connected with this read- vance. The lithostratigraphy of the area was first studied to determine the type of environment during the final deglaciation.

\section{STUDY AREA AND METHODS}

The area investigated is about $20 \times 30 \mathrm{~km}$ and situated between the Giants Range in the south and the town of Tower in the 

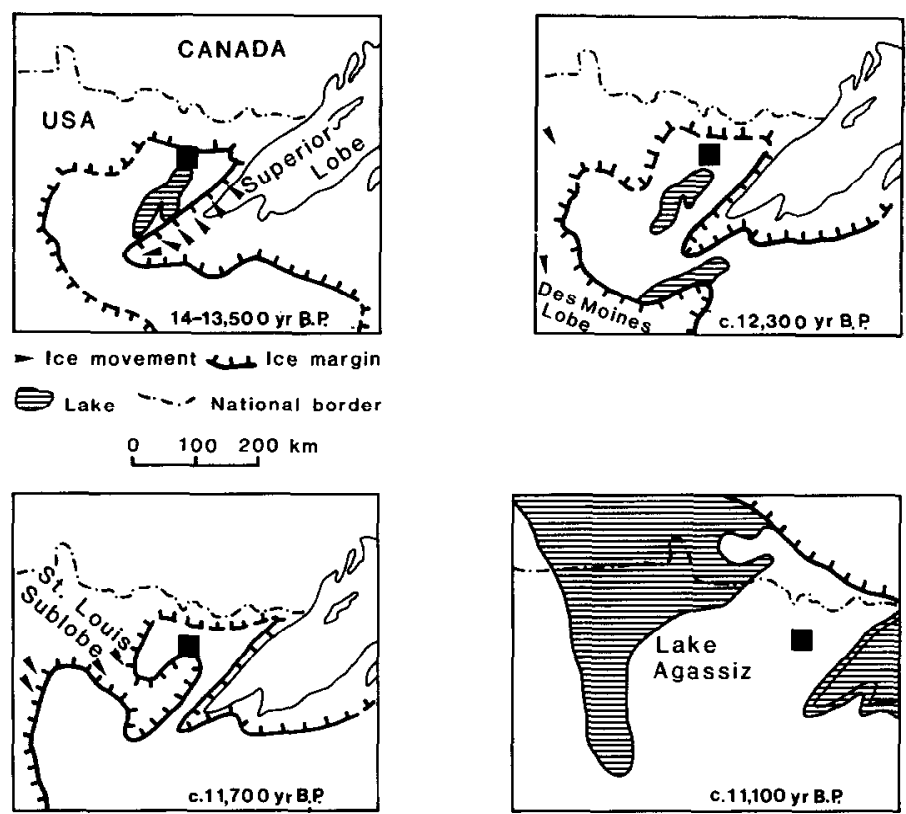

FIG. 3. Deglaciation-glaciation chronology in the Lake Superior region between ca. 14,000 and 11,000 yr B.P. according to Clayton and Moran (1982). The study area is marked by a black square.

north (Fig. 2). The altitudinal differences are quite significant, with altitudes as high as $550 \mathrm{~m}(1800 \mathrm{ft})$ in the Giants Range and as low as about $412 \mathrm{~m}(1350 \mathrm{ft})$ at Vermillion Lake to the north. An important watershed divides the southeastern portion, which is drained by the Embarrass River to the south through the Embarrass channel (Fig. 4) via Sabin Lake (No. 5 in Fig. 2) into St. Louis River, and the rest of the area, which is drained to the north by the Pike River and the West Two River into Vermillion Lake.

Apart from the Giants Range, the area is slightly hummocky low relief terrain traversed by small rivers and marked by many small, generally round lake basins. Two distinct hummocky ridges trend west-east and, in places, reach altitudes of about $460 \mathrm{~m}$.

The bedrock geology of the area is rather complex (Winter et al., 1973) Argillite and graywacke crop out south of the Mesabi Range, which is composed of the Biwabik Iron Formation. The Giants Range is composed of granite and undifferentiated metasedimentary rocks. North of the Gi- ants Range is a belt of granite $2-15 \mathrm{~km}$ wide, beyond which metasedimentary and volcanic rocks extend to Vermillion Lake.

The red clayey till of the St. Louis Sublobe dominates the southern slopes of the Giants Range, whereas on the highest parts of the range, thin Rainy Lobe drift overlies bedrock (Winter et al., 1973). Northern slopes are dominated by sand and gravel, often as eskers and hummocks. North of the range a low-lying area $(<450 \mathrm{~m})$ is dominated by sand and silt. This is often referred to as the area of Glacial Lake Norwood (Fig. 2). To the north follows an area characterized by poorly sorted sand and gravel, as well as till-like deposits; the southern and northern parts of this area are rather hummocky, with flatter terrain between. South of Vermillion Lake only thin drift is found over bedrock. Between Vermillion Lake and the Giants Range are many low areas underlain by peaty deposits.

\section{Fieldwork}

The lithostratigraphy was examined at 
more than $\mathbf{4 0}$ gravel pits and road sections. At each site clast and carbonate content, grain-size, sorting, paleocurrent directions, and morphology were described, and the morphology of all easily accessible lakes was checked to identify possible kettle lakes, which may lack sediments recording the earliest stages of deglaciation because of the persistence of stagnant ice.

Field reconnaissance for lakes having the oldest possible sediments revealed that almost all lakes within the area may be kettle lakes. Therefore, it was decided to core lakes in areas of different landscape type and different morphology. At each site at least two different parts of the lake were cored using a square-rod piston corer, $5 \mathrm{~cm}$ in diameter and $1 \mathrm{~m}$ long (Wright, 1967). The cores were extruded and described in the field and transported to the laboratory for analyses.

\section{Laboratory Methods}

The proportions of organic matter and carbonate were estimated after ignition at $550^{\circ}$ and $925 \mathrm{C}^{\circ}$, respectively. Due to very low organic content, many pollen samples were treated according to both the procedures outlined in Faegri and Iversen (1975) and the method described by Björck et al. (1978). In some samples from Heikkilla Lake, Lycopodium tablets (Stockmarr, 1971) were added to calculate pollen concentration. Generally, at least 300 pollen grains were counted per sample.

Fourteen levels from the six different coring sites were radiocarbon-dated (see Table 2). Organic carbon was estimated as percentage dry weight by the radiocarbon laboratory to assess any dating errors caused by contamination by redeposited organic matter (cf. Björck and Håkansson, 1982). In all but two samples anthracite$\mathrm{CO}_{2}$ was added to permit measuring; to minimize the standard error, additional measurements were made on many samples.

\section{Statistical Methods}

Correspondence analysis (e.g., Hill,
1974; Greenacre, 1984) was used to find common patterns within the pollen records. This numerical scaling method ordinates variables (pollen types) and individuals (pollen samples) simultaneously on the same axes. In a data set consisting of many pollen stratigraphies it can illustrate how different samples are influenced by the different pollen types. This method also explores "hidden" relationships among samples, pollen types, and sites; if the pollen stratigraphy among the analyzed sites is uniform, this method will undoubtedly reveal any major hiatuses. The relatively low "noise level," owing to the fact that variables and individuals have implicit weight, usually means that only the first few axes are of importance.

\section{RESULTS}

\section{Glacial and Extraglacial Stratigraphy and Morphology}

Mapping of glacial and extraglacial deposits revealed a local lithostratigraphy that can be partially correlated with units described by Winter (1973).

The bedrock is commonly covered by a sandy-silty diamicton containing clasts of local bedrock as well as of gabbro and basalt from the northeast. When found on the surface it is usually situated above $440-445$ $\mathrm{m}$ and has a low local relief. It is correlated with Winter's (1973) "bouldery till" and was deposited by the Rainy Lobe.

This Rainy Lobe till is overlain by wellsorted sand and gravel with a great morphologic variability. It is dominated by Rainy Lobe clasts, but the carbonate content locally is enough to react with $\mathrm{HCl}$. Within the Vermillion moraine (Fig. 2) these glaciofluvial deposits are usually in the form of deltas or kames with hummocky relief. Between these moraines and in the Embarrass channel the deposits occur as eskers (Fig. 4), but on the northern edge of the Giants Range all three geomorphic features can be found. The morphology and the internal composition and structures (e.g., collapsed bedding) indicate that the deposits were 


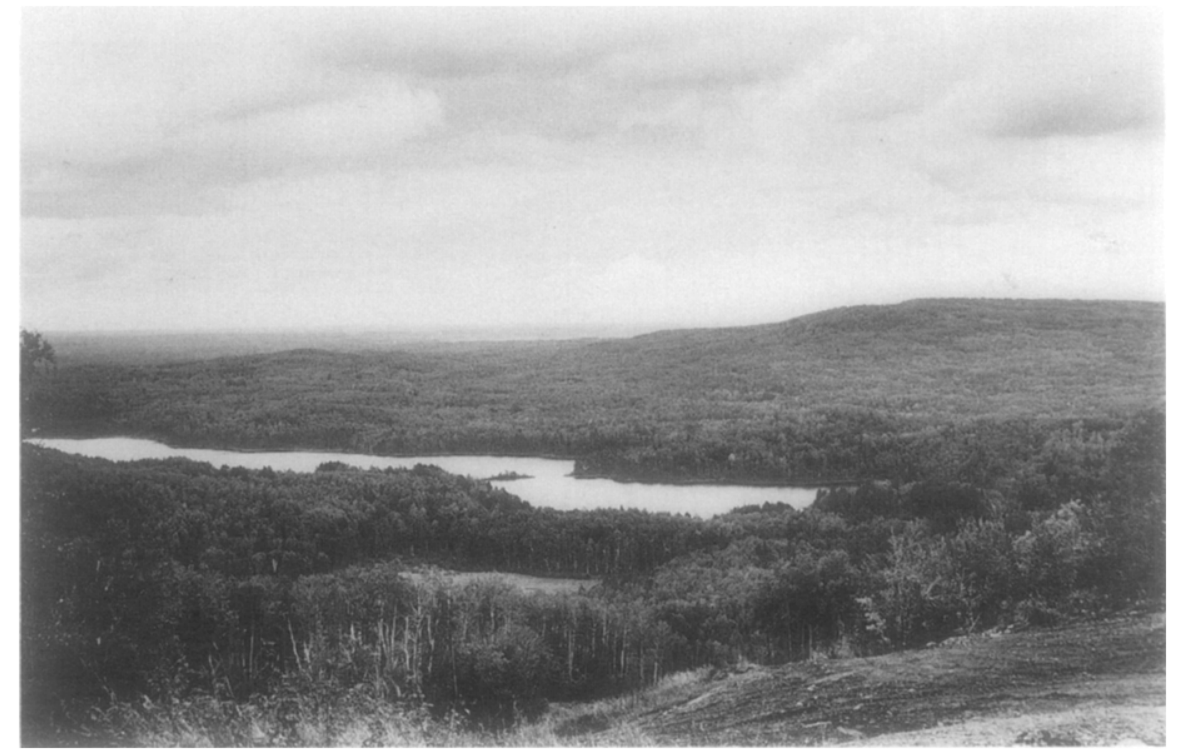

FIG. 4. The northern part of the Embarrass channel and Sabin Lake photographed toward the northeast from the Giants Range. Note the esker in the middle of the lake.

formed in contact with the receding Rainy Lobe, and that during its final stage this lobe was characterized by gradually wasting, debris-covered stagnant ice.

Overlying these glacial and glaciofluvial deposits are two contrasting units. One, consisting of silt and sand and locally some clay, is found in the southern parts of the area at altitudes below about $450 \mathrm{~m}(1470$ $\mathrm{ft}$ ), usually in flat river valleys of the Sand and Embarrass Rivers. Sedimentary structures indicate that these sediments were transported from the north or west. They seem to fill all depressions cxcept those occupied by kettlehole lakes in this low-lying area, so they must have been deposited before the dead ice had finally melted.

The other stratigraphic unit is a reddishbrown silty-clayey diamicton. It was found only at a small gravel pit $14 \mathrm{~km}$ north of Biwabik (Fig. 2), where it overlies the glaciofluvial deposits (Fig. 5). On the basis of color and bedrock content this unit is correlated with Winter's (1973) "red clayey till," which was deposited by the St. Louis sublobe. However, the site is situated far east of and 8-10 km north of the supposed limit (Winter 1971) of this sublobe. Its relationship to the sand and silt described above is unclear. The pit later was filled in and restored, making further detailed studies of this diamicton impossible.

The uppermost unit consists of fine sand, found mostly in the southern part of the area; although it generally forms a thin sand cover, it also occurs locally as small dunes. This unit, of inferred eolian origin, probably formed after the area was drained and the fluviatile-lacustrine sands and silts were exposed to wind action, but before the ground was covered by continuous vegetation.

\section{Sequence of Events Indicated by Stratigraphy and Morphology}

The margin of the Rainy Lobe receded northward, leaving debris-rich stagnant ice behind. Whether or not the area north of the Giants Range was already occupied by water cannot be determined. The later infilling of sand and silt among masses of stagnant ice may correlate with a partial damming of the Embarrass channel by the advancing St. Louis Sublobe in combina- 


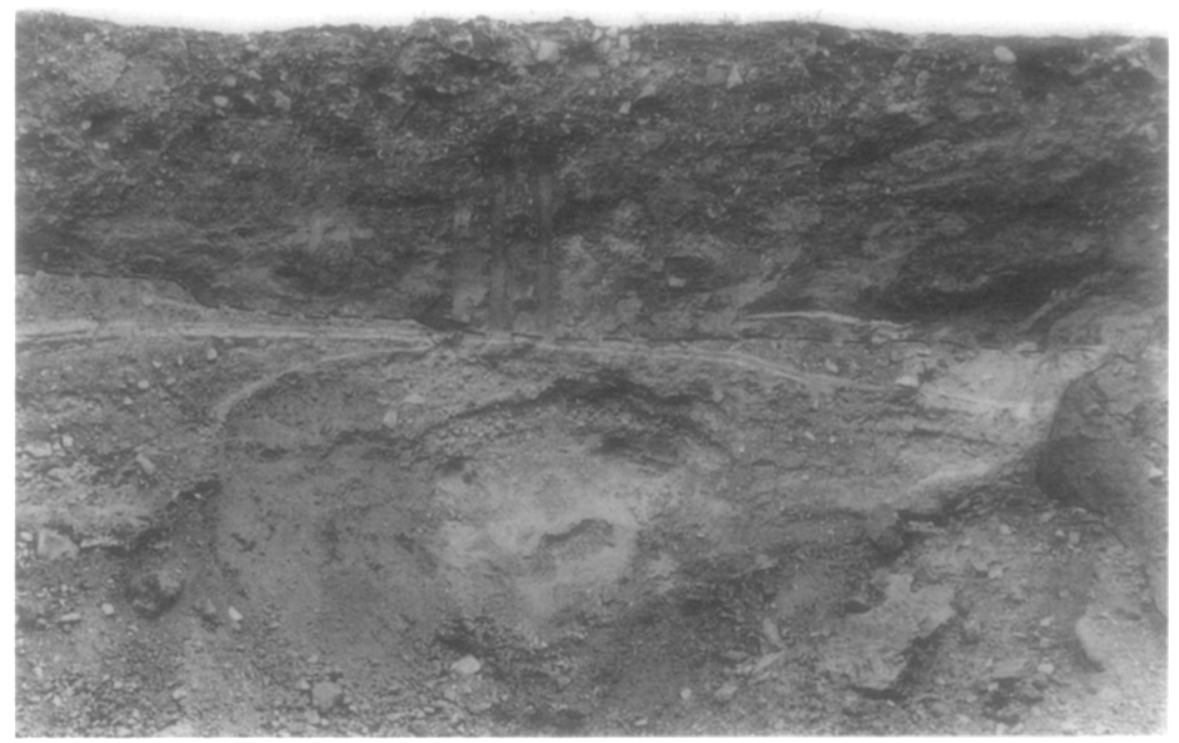

Fig. 5. The only known exposure in the study area of the assumed "red clayey till," overlying glaciofluvial deposits with disturbed silty sediments inbetween. The boundaries between the different units are indicated by dashed lines.

tion with sediment transport from the retreating Rainy Lobe to the north. During the inferred damming and sedimentation (up to perhaps $450 \mathrm{~m}$ ), the resulting lake gradually became shallower. If the reddishbrown till is related to the St. Louis Sublobe, it must have been deposited from the west or the south during the maximum ice expansion which should have been during the inferred damming. The lake waters may have accelerated melting of both dead ice and an actively calving ice front. This glacial lake (presumably Glacial Lake Norwood) was drained when the St. Louis Sublobe retreated from the Giants Range and released considerable water through the Embarrass channel. The sandy and silty river and lake beds then were exposed and subjected to wind erosion.

If this interpretation is correct, the possibilities of finding limnic sediments closely connected with the deglaciation of the Rainy Lobe are limited. However, it should at least be possible to find kettle lakes that formed more or less contemporaneously with the St. Louis Sublobe, because the dif- ference in time between the readvance of this lobe and the previous recession of the Rainy Lobe is assumed to have been 2000$3000 \mathrm{yr}$ (Clayton and Moran, 1982). In this case, the lake sediments might record the readvance and recession of the St. Louis Sublobe. For this reason, lake sediments in different parts of the study area were sampled.

\section{Site Descriptions of the Cored Lakes}

The northernmost lake studied is the southern of the two Lempia Lakes $\left(47^{\circ} 43^{\prime} \mathrm{N}, 92^{\circ} 15^{\prime} \mathrm{W}\right.$, altitude $446 \mathrm{~m}$, area about $5 \mathrm{ha}$ ), situated $22 \mathrm{~km}$ north of Aurora (Nos. 2 and 3 in Fig. 2). After several corings in different parts of the lake, two sites were chosen for sampling, one (S. Lempia Lake 1) in the southwestern bay of the eastern part of the lake, with a water depth of 3 $\mathrm{m}$, and the other (S. Lempia Lake 2) in the deeper $(7 \mathrm{~m})$ western part of the lake. The lake is a kettle, with steep slopes rising above the shore and surrounded by hummocky glaciofluvial deposits. 
Heikkilla Lake $\left(47^{\circ} 39^{\prime} 16^{\prime \prime} \mathrm{N}, 92^{\circ} 10^{\prime} 24^{\prime \prime} \mathrm{W}\right.$, altitude $439 \mathrm{~m}$, area about $50 \mathrm{ha}$ ), situated $10 \mathrm{~km}$ southeast of the Lempia lakes (No. 1 in Fig. 2), is one of the larger lakes within the study area. After a few corings in the northern part of the lake, a final site was chosen in the central part of the northern bay. The lake is bounded on the southeast, south, and partly also on the west by hummocky glaciofluvial deposits. To the north and northeast, however, a flat swampy area extends to the meandering Embarrass River. The shores of the lake are gentler than those of the Lempia lakes, but only $700 \mathrm{~m}$ southeast of the lake the glacial hummocks reach $30 \mathrm{~m}$ above the lake level. The lake basin may not be a kettle, so it was chosen as a feasible site to recover older lake sediments.

A small pond (about $1.1 \mathrm{ha}$ ), here named Swamp Lake $\left(47^{\circ} 32^{\prime} 52^{\prime \prime} \mathrm{N}, 92^{\circ} 18^{\prime} \mathrm{W}\right.$, elevation $435 \mathrm{~m}$ ) is situated $12 \mathrm{~km}$ northnortheast of Biwabik (No. 6 in Fig. 2) within the rather large swampy area north of the Embarrass channel. It is intersected by sandy gravelly ridges and hummocks (possibly eskers and kames), that are locally covered by eolian sand. The coring was made from the peaty southeastern shore.

The Embarrass channel (Fig. 4) is occupied by a lake $6 \mathrm{~km}$ long and $200-500 \mathrm{~m}$ wide, divided into two different portions (Sabin Lake in the north and Wynne Lake in the south) by a strait only $25 \mathrm{~m}$ wide (The Narrows). Corings were carried out in two different parts $\left(47^{\circ} 34^{\prime} 46^{\prime \prime} \mathrm{N}, 92^{\circ} 17^{\prime} 40^{\prime \prime} \mathrm{W}^{\prime}\right.$; and $47^{\circ} 35^{\prime} 23^{\prime \prime} \mathrm{N}, 92^{\circ} 18^{\prime} 05^{\prime \prime} \mathrm{W}$, elevation 416 m) of Sabin Lake (Nos. 4 and 5 in Fig. 2), named Sabin Lake 1 and Sabin Lake 2, respectively. The St. Louis Sublobe is assumed to have at least partly entered Wynne Lake from the south but not Sabin Lake. The objective, in part, was to date the oldest lake sediments in the Embarrass channel. The steep hummocky shores are dominated by till and glaciofluvial deposits, and a few eskers emerge in the southern part of Sabin Lake as elongated islands (Fig. 4) and narrow peninsulas.

\section{Stratigraphy of the Lake Sediments}

The total organic matter and carbonate content of the four lakes (Fig. 2) are plotted in Figure 6 along with ${ }^{14} \mathrm{C}$ dates, ${ }^{13} \mathrm{C}$ values, and organic carbon content. In the Heikkilla Lake diagram pollen concentration values are also included.

Abrupt and significant changes in grain size and organic content are apparent in all sections except that of Heikkilla Lake (Table 1, Fig. 6). The ${ }^{14} \mathrm{C}$ dates (Table 2, Fig. 6) from all sites suggest that the several sequences together should contain a good record of the area's vegetation history between 12,000 and 9000 yr B.P.

\section{Pollen Stratigraphy}

Of the six pollen diagrams prepared only four are presented here (Fig. 7). The Sabin Lake 2 and Swamp Lake sections are short and do not reveal any significant differences from the other four sections.

Correlation of the pollen diagrams by means of pollen stratigraphy and ${ }^{14} \mathrm{C}$ chronology was confounded by apparent hiatuses, in some cases lengthy. Heikkilla Lake is the only lake that seems to contain a more or less continuous record from ca. 12,000 to ca. 10,000 yr B.P. No part of the pollen stratigraphy shows signs of cooling and warming trends related to advance and retreat of the St. Louis Sublobe. In that respect the results confirm Cushing's (1967) and Birks' $(1976,1981)$ data showing a more or less progressive late Wisconsin climatic warming. On the other hand my results suggest an alternative working hypothesis, namely, that the complex lithostratigraphy, with possible hiatuses in most cores, resulted either from the described glacial events including damming and drainage of Glacial Lake Norwood or from the drainage of the early eastern arm of Glacial Lake Agassiz (Lake Koochiching), or from both. 

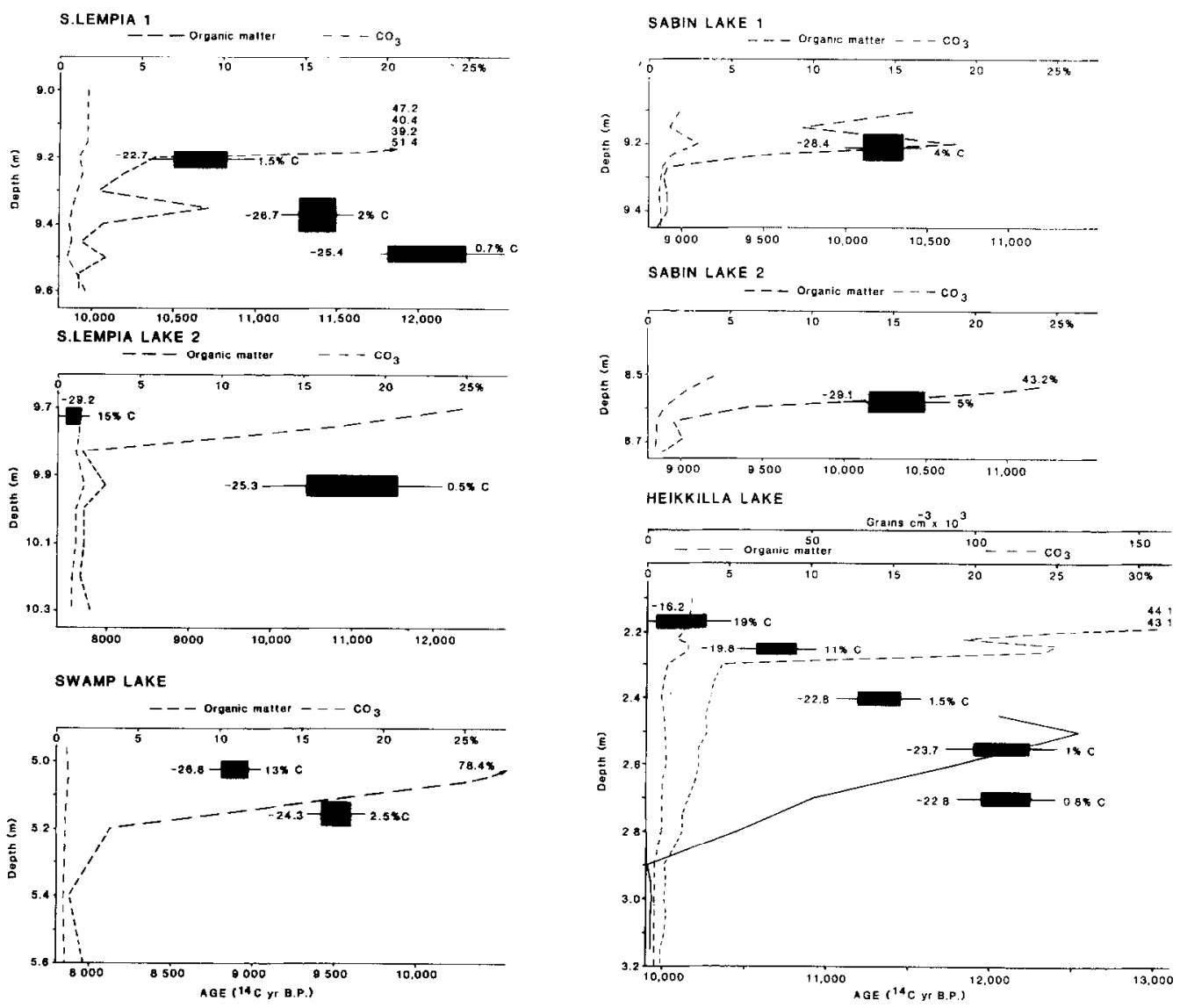

SWAMP LAKE

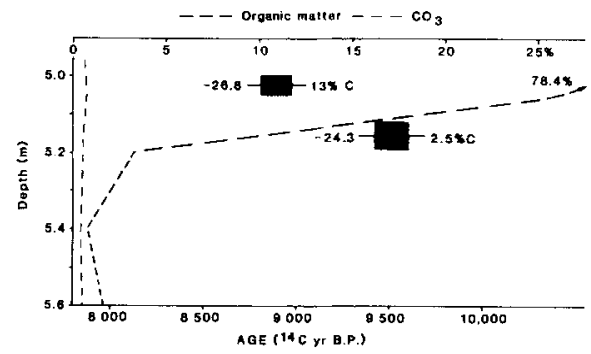

Fig. 6. Diagrams showing loss on ignition and carbonate values for the six sections analyzed. The ${ }^{14} \mathrm{C}$ datings are related to depth and include single and double standard errors. For each date the ${ }^{13} \mathrm{C}$ value (\%) is shown to the left, and the value for organic carbon (in \% of dry weight) is shown to the right. Note that pollen concentration values (full line) also were calculated for parts of the section from Heikkilla Lake.

This hypothesis was tested by assuming that the late Wisconsin vegetation history of this small study area had been fairly uniform, and that the missing pollen spectra would be detected only by detailed statistical analysis. The pollen stratigraphies were compared with the assumed continuous Heikkilla record as well as with each other by correspondence analysis on all pollen sequences simultaneously (Figs. 8 and 9). Nine different groups of pollen spectra can be discerned in the first two dimensions of the analysis (A-I in Fig. 8). A more detailed picture of a recently deglaciated and revegetated area in northern Minnesota emerges when the pollen assemblages of these nine groups are described (Fig. 9).

\section{Interpretation of the Pollen Stratigraphy}

Tundra vegetation characterized by, e.g., Artemisia, grasses, and weeds, as well as willow, dominated in the beginning (groups $A$ and $B$ ). The rather high Picea values have often been interpreted as a product of distant transport from the south over open treeless areas, because at that time spruce was migrating northward from southern Minnesota (Cushing, 1967; Wright and Watts, 1969; Birks, 1976). High Pinus values at the same levels support this interpre- 
TABLE 1. LithostratigRAPHY OF THE ANALYZED LAKE-Sediment Sections

\begin{tabular}{|c|c|c|}
\hline $\begin{array}{c}\text { Depth } \\
\text { below } \\
\text { water } \\
\text { surface } \\
(\mathrm{m})\end{array}$ & Layer & Lithostratigraphy \\
\hline \multicolumn{3}{|c|}{ Heikkilla Lake (water depth: $1.0 \mathrm{~m}$ ) } \\
\hline $1.92-2.19$ & 6 & Algal gyttja, brownish red \\
\hline $2.19-2.235$ & 5 & Clay gyttja, rich in algae, light brown \\
\hline $2.235-2.27$ & 4 & Clayey gyttja, rich in algae, brown \\
\hline $2.27-2.52$ & 3 & Silty clay gyttja, light brownish gray \\
\hline $2.52-2.80$ & 2 & $\begin{array}{l}\text { Silty clay, very slightly organic, light } \\
\text { gray }\end{array}$ \\
\hline $2.80-3.35$ & 1 & Sandy clayey silt, gray \\
\hline \multicolumn{3}{|c|}{ S. Lempia Lake 1 (water depth: $3.0 \mathrm{~m}$ ) } \\
\hline $8.70-9.17$ & 7 & $\begin{array}{l}\text { Coarse-detritus gyttja, dark brown; } \\
\text { rich in mosses at } 9.17-9.15 \text { and } \\
9.12-9.10 \mathrm{~m}\end{array}$ \\
\hline $9.17-9.19$ & 6 & Sandy clay gyttja, brown \\
\hline $9.19-9.33$ & 5 & Gyttja clay, brownish gray \\
\hline $9.33-9.45$ & 4 & $\begin{array}{l}\text { Sandy gravelly pebbly gyttja clay, } \\
\text { brown; rich in mosses and coarse } \\
\text { organic matter, especially between } \\
9.37 \text { and } 9.33 \mathrm{~m}\end{array}$ \\
\hline $9.45-9.49$ & 3 & Silty clay, gray \\
\hline 9.49 & 2 & Silty clay, brown \\
\hline $9.53-9.65$ & 1 & Clayey silt, gray \\
\hline $9.65-9.76$ & 6 & Clayey algal gyttja, dark \\
\hline $9.76-9.89$ & 5 & $\begin{array}{l}\text { Sandy pebbly gravel with organic } \\
\text { matter, grayish brown }\end{array}$ \\
\hline $9.89-9.97$ & 4 & Gyttja clay, brownish gray \\
\hline $9.97-10.17$ & 3 & $\begin{array}{l}\text { Silty clay, gray with patchy } \mathrm{FeS} \\
\text { coloring }\end{array}$ \\
\hline $10.17-10.26$ & 2 & Clayey silt, gray \\
\hline & 1 & Sandy silt, gray \\
\hline \multicolumn{3}{|c|}{ Sabin Lake 1 (water depth: $5.2 \mathrm{~m}$ ) } \\
\hline $8.00-9.13$ & 5 & $\begin{array}{l}\text { Silty clayey algal gyttja, brownish } \\
\text { black }\end{array}$ \\
\hline $9.13-9.25$ & 4 & Silty clayey gyttja, grayish black \\
\hline $9.25-9.31$ & 3 & Sanc \\
\hline 9.42 & 2 & Faintly laminated clayey silt, gray \\
\hline $9.42-9.55$ & $\overline{1}$ & Sandy gravel, gray \\
\hline \multicolumn{3}{|c|}{ Sabin Lake 2 (water depth: $5.3 \mathrm{~m}$ ) } \\
\hline $\begin{array}{l}8.00-8.29 \\
8.29-8.605\end{array}$ & $\begin{array}{l}4 \\
3\end{array}$ & $\begin{array}{l}\text { Algal fine-detritus gyttja, black } \\
\text { Silty clayey algal gyttja, grayish black }\end{array}$ \\
\hline $8.605-8.66$ & 2 & Silty clayey sand, dark gray \\
\hline $8.66-8.77$ & 1 & Silty sand, gray \\
\hline \multicolumn{3}{|c|}{ Swamp Lake (from peat shore) } \\
\hline $4.50-5.10$ & 3 & $\begin{array}{l}\text { Sandy peaty coarse-detritus gyttja, } \\
\text { brown }\end{array}$ \\
\hline $5.10-5.25$ & 2 & $\begin{array}{l}\text { Sand rich in organic matter, grayish } \\
\text { brown }\end{array}$ \\
\hline $5.25-5.68$ & 1 & $\begin{array}{l}\text { Sand with some organic matter, } \\
\text { brownish gray }\end{array}$ \\
\hline
\end{tabular}

tation, because pine was certainly not present in the area. On the other hand, Jacobson et al. (1987) think that spruce woodland existed very close to the ice margin south and southwest of the Great Lakes during deglaciation between 18,000 and
12,000 yr B.P. They also claim that spruce was present along most parts of the receding ice margin at $12,000 \mathrm{yr}$ B.P.

Sometime between 12,000 and $11,500 \mathrm{yr}$ B.P. birch (possibly tree birch) became abundant, together with willow and various herbs. Ash possibly also was present; its highest values were actually reached before birch was most abundant. Such a development has been found both north [Rattle Lake (Björck, 1985)] and far south [e.g., Kirchner Marsh (Wright et al., 1963) and Wolf Creek (Birks, 1976)] of the study area. Pollen concentration values increased markedly at Heikkilla Lake (Fig. 6) where the vegetation probably was a birch tundra parkland. This phase (group C) seems to have persisted for at least $1000 \mathrm{yr}$. A similar but less detailed and long-lasting birch phase is recorded in zone WL-2 at Weber Lake (Fries, 1962), zone LC-1 at Lake of the Clouds (Craig, 1972), zone KYL-2 of Kylen Lake (Birks, 1981), and zone R3 at Rattle Lake (Björck, 1985). In contrast to zone KYL-2, however, there is no indication that the birch pollen at Heikkilla Lake represent dwarf birch. The long birch tundra parkland phase in this area shows either that the climate was stable for as much as $1000 \mathrm{yr}$ or that spruce immigration considerably lagged climatic change.

Between 10,600 and 10,200 yr B.P. a gradual change to a forest of spruce, ash, and birch was soon followed by denser forest (group E) dominated by spruce and larch; both pine and elm seem to have been present, as well as birch, oak, and balsam fir. In contrast to some of the lakes shown in Figure 1 (e.g., Kylen Lake, Weber Lake, and Rattle Lake), the spruce phase lasted for only a short time before pine gradually became the dominant tree (groups $\mathrm{G}$ and H). Amundson and Wright (1979) concluded that the spruce decline and pine expansion in Minnesota at the end of the Pleistocene was not caused by increased fire incidence but rather by climatic change. In this area pine may also have been favored by the dry sandy soils in most 
Table 2. Radiocarbon Dates from the Six Coring Sites

\begin{tabular}{lccccccc}
\hline Lake site & $\begin{array}{c}\text { Sample } \\
\text { depth } \\
(\mathrm{cm})\end{array}$ & $\begin{array}{c}\text { Org. } \\
(\%)\end{array}$ & $\begin{array}{l}\mathrm{CO}_{3} \\
(\%)\end{array}$ & $\begin{array}{c}\text { Org. C } \\
(\%)\end{array}$ & $\begin{array}{c}{ }^{13} \mathrm{C} \\
(\%)\end{array}$ & $\begin{array}{c}\text { Lab. } \\
\text { No. }\end{array}$ & $\begin{array}{c}{ }^{14} \mathrm{C} \text { age } \\
\text { (yr B.P.) }\end{array}$ \\
\hline Heikkilla & $268-272$ & 2.6 & 0.9 & 0.8 & -22.8 & Lu-2556 & $12,100 \pm 150$ \\
& $253-257$ & 3.2 & 1.2 & 1.0 & -23.7 & Lu-2496 & $12,070 \pm 170$ \\
& $238-242$ & 3.9 & 0.9 & 1.5 & -22.8 & Lu-2497 & $11,320 \pm 130$ \\
& $223.5-227$ & 24.7 & 2.5 & 11.0 & -19.8 & Lu-2498 & $10,690 \pm 120$ \\
Lempia 1 & $215-219$ & 43.1 & 2.6 & 19.0 & -16.2 & Lu-2499 & $10,110 \pm 150$ \\
& $946-951$ & 2.8 & 0.5 & 0.7 & -25.4 & Lu-2555 & $12,050 \pm 240$ \\
& $932-942$ & 5.9 & 0.7 & 2.0 & -26.7 & Lu-2500 & $11,380 \pm 100$ \\
Lempia 2 & $918-923$ & 5.9 & 1.2 & 1.5 & -22.7 & Lu-2501 & $10,660 \pm 160$ \\
& $990-996$ & 2.9 & 1.6 & 0.5 & -25.3 & Lu-2502 & $11,500 \pm 550$ \\
Sabin 1 & $970-975$ & 21.2 & 1.3 & 15.0 & -29.2 & Lu-2503 & $7,580 \pm 90$ \\
Sabin 2 & $917-925$ & 13.0 & 2.1 & 4.0 & -28.4 & Lu-2506 & $10,230 \pm 120$ \\
Swamp & $855-861$ & 13.8 & 1.6 & 5.0 & -29.1 & Lu-2507 & $10,320+170$ \\
& $512-519$ & 3.3 & 0.4 & 2.5 & -24.3 & Lu-2504 & $9,510 \pm 90$ \\
& $500-505$ & 26.9 & 0.7 & $>13.0$ & -26.8 & Lu-2505 & $8,890 \pm 80$ \\
\hline
\end{tabular}

of the area north of the Giants Range and by the uplands themselves. Spruce became less common, while elm and birch, and later also alder, became important components of a rather mixed forest.

Thus, a detailed vegetation development from late Wisconsin to early Holocene emerges from the grouping in Figure 8. It also shows, when all samples are added together, that these 60 samples represent a continuous record from ca. 12,500-12,000 yr B.P. to at least ca. 9000 yr B.P. This conclusion is supported by the ${ }^{14} \mathrm{C}$ dates.

\section{"Hiatus" Stratigraphy}

When the results from the correspondence analysis are set out not as a biplot (as in Fig. 8) but stratigraphically, a different picture emerges (Fig. 9). As pointed out, the lithostratigraphy of most of the cored lake sediments indicates significant changes in sedimentation, possibly marking hiatuses. This interpretation is supported by the difficulties in correlating among the different pollen stratigraphies despite the many ${ }^{14} \mathrm{C}$ dates. So when each analyzed sample was placed stratigraphically in its statistical group of affiliation (A through I, Fig. 9) the suspected hiatuses were revealed very clearly. However, at least from a theoretical viewpoint, some of these inferred hiatuses might become shorter, or even disappear, if pollen samples were more closely spaced and the sedimentation rate had been extremely slow during hiatuses.

The record from Heikkilla Lake seems continuous, but all the other sections probably contain hiatuses. No really long hiatus seems to exist in Lempia 1, however, despite the presence of the coarse and mixed layer (Table 1), the pollen from which indicates that it belongs to the younger part of group $C$ (Fig. 9). The absence of any sample belonging to groups $E$ and $G / H$, as well as the presence of sandy layer 6 , suggests at least an irregular sedimentation environment at Lempia 1 during the deposition of layers 4-6. A hiatus 2000-3000 yr long is indicated at Lempia 2 (Fig. 9), coinciding with the very coarse and slightly organic layer 5 (Table 1). This layer probably corresponds to layer 4 at Lempia 1; both are underlain by sediments of group B and partly also of group C.

At Sabin Lake the absence of groups $C$ and $D$ and most of group $E$ implies hiatuses of 1000-1500 yr (Fig. 9). At Sabin 1 the hiatus is marked by layer 3, consisting of sand, gravel, and some organic matter, as well as by the marked change into layer 4 (Fig. 6). In Sabin 2 the assumed hiatus is shown by the marked change between layers 2 and 3.

At Swamp Lake the development is slightly different. In contrast to the other 


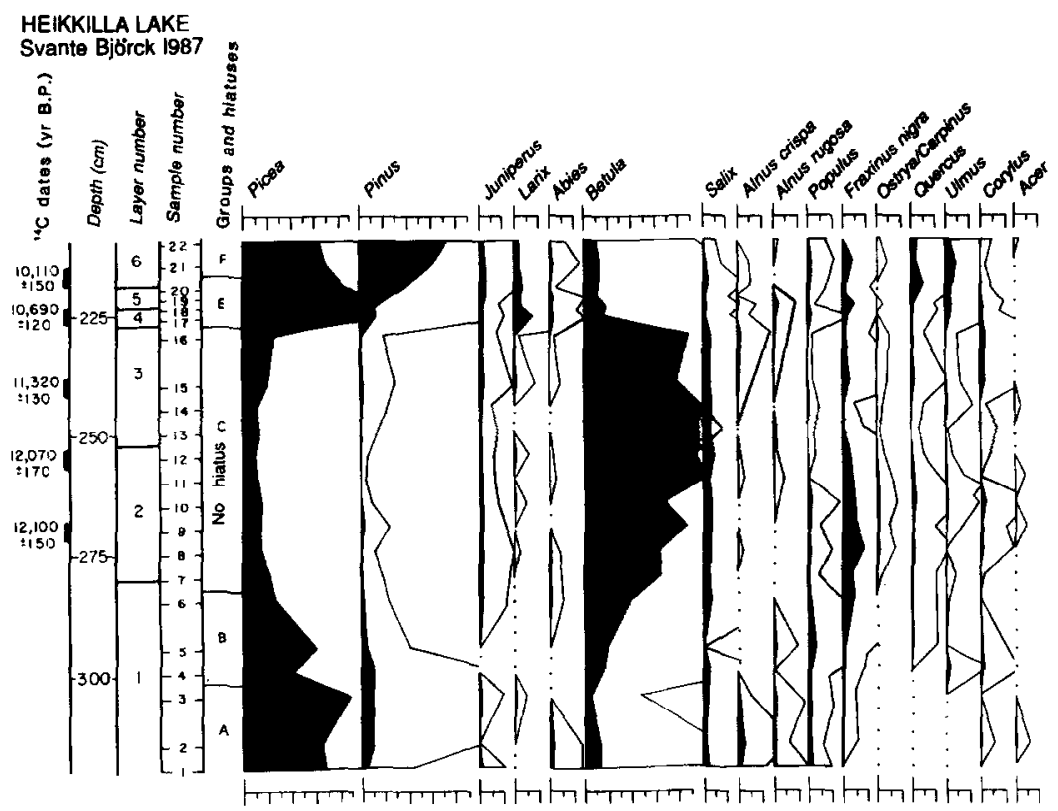

LEMPIA I

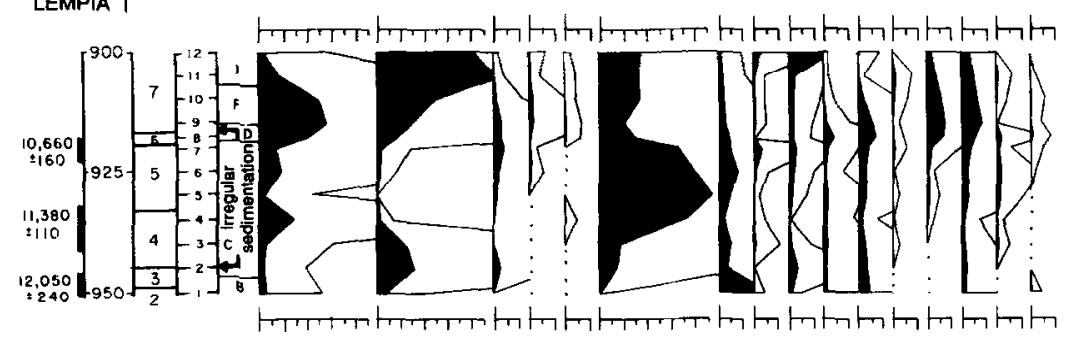

LEMPIA 2

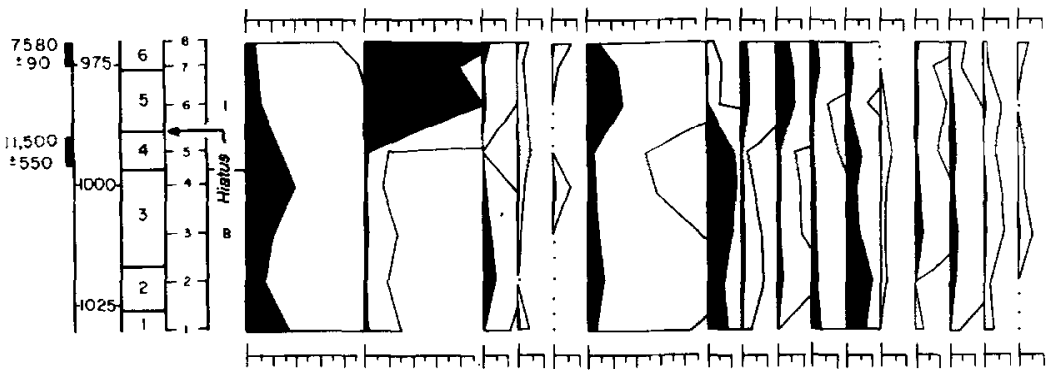

SABIN 1

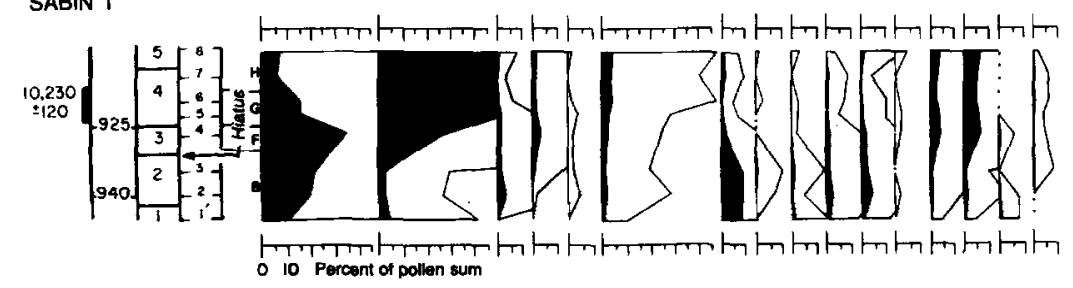

Fig. 7. Pollen diagrams for Heikkilla Lake (No. 1 in Fig. 2), S. Lempia Lake 1 (No. 2 in Fig. 2), S. Lempia Lake 2 (No. 3 in Fig. 2), and Sabin Lake 1 (No. 4 in Fig. 2). 

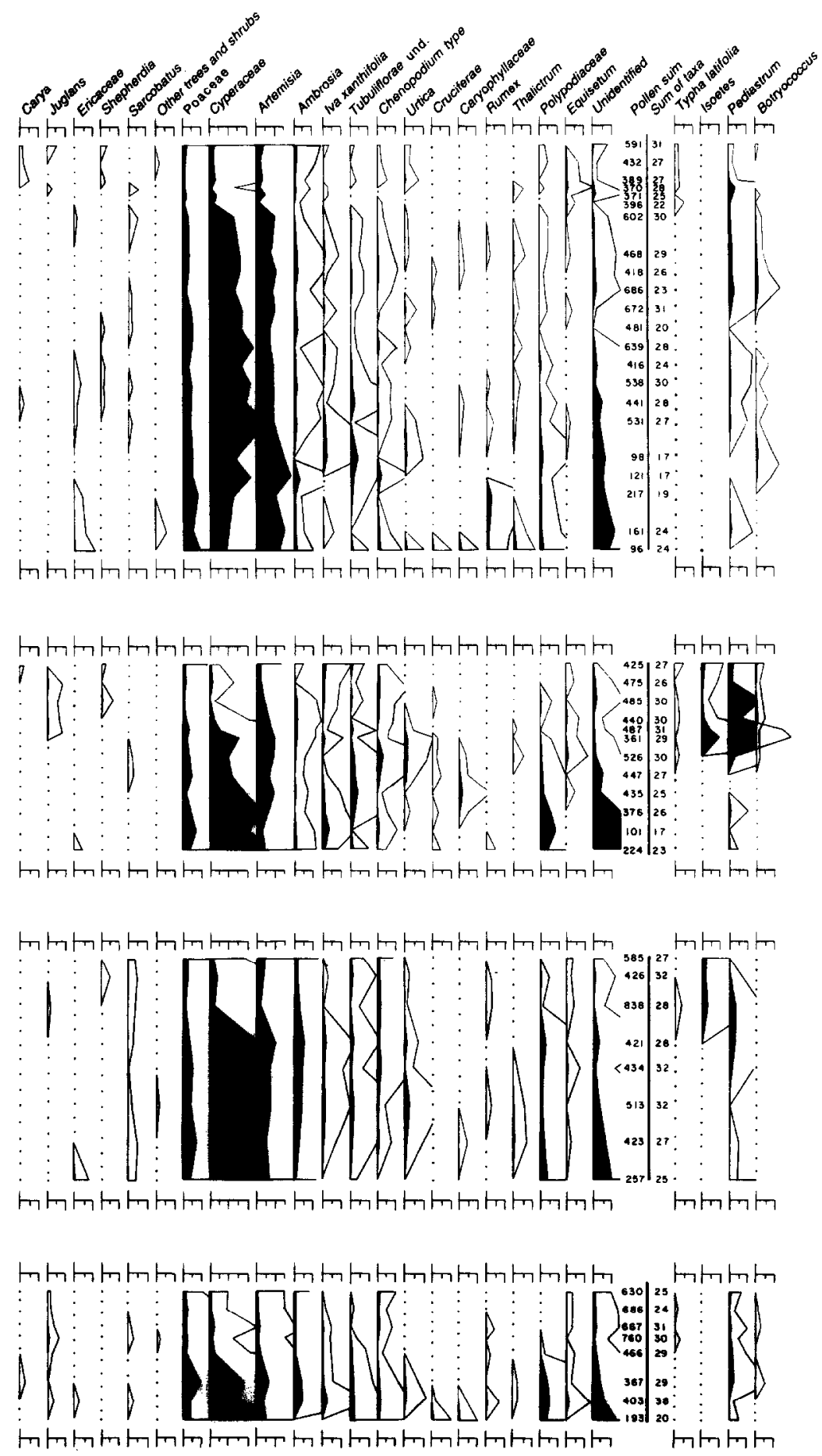

Fig. 7-Continued 


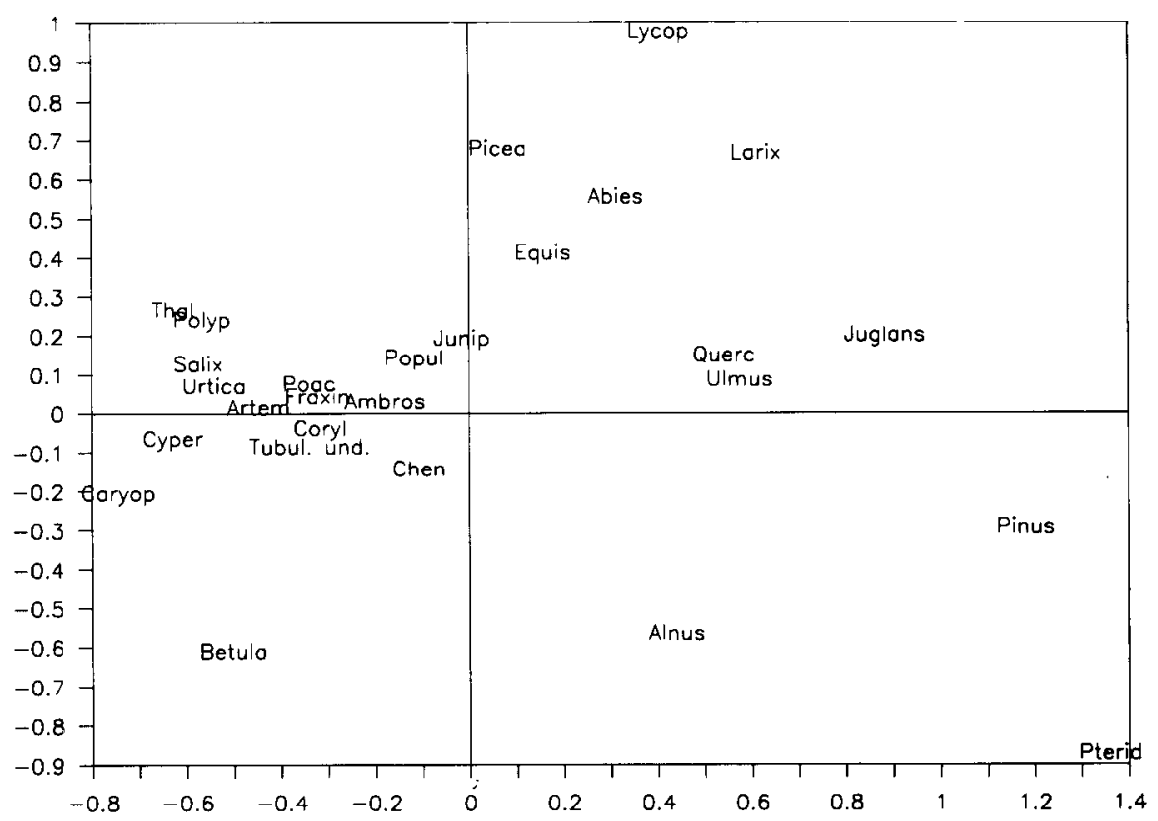

Correspondence analysis

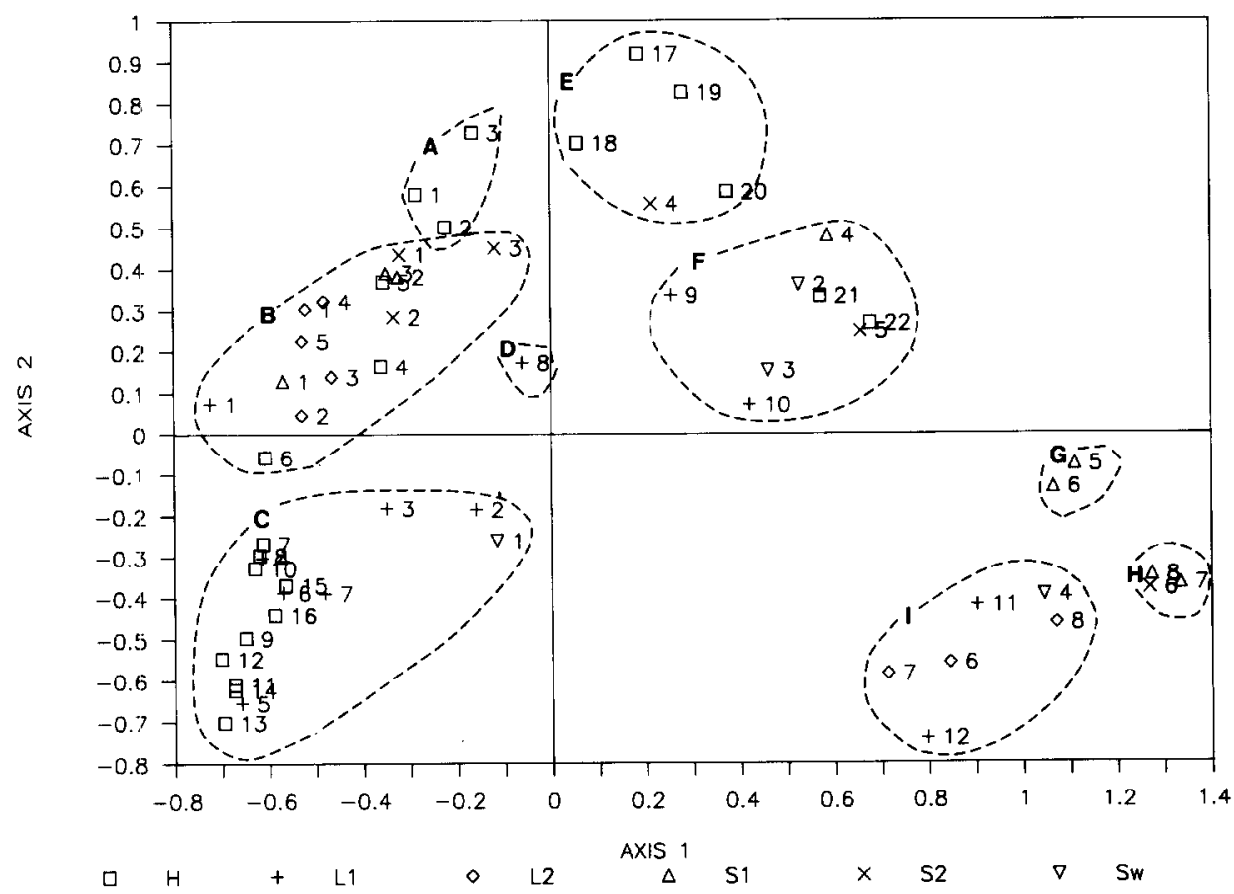

Fig. 8. Plots of the 27 most common pollen types (top) and the 60 pollen-analyzed samples (bottom) with the nine different groups (A-I) from the six described cores on the first two correspondence analysis axes, which account for $60 \%$ of the variance. Note the explanation below, $\mathrm{H}=$ Heikkilla, $\mathrm{L} 1$ $=\mathrm{S}$, Lempia 1, L2 = S. Lempia 2, S1 = Sabin 1, S2 = Sabin 2, and Sw $=$ Swamp Lake. 


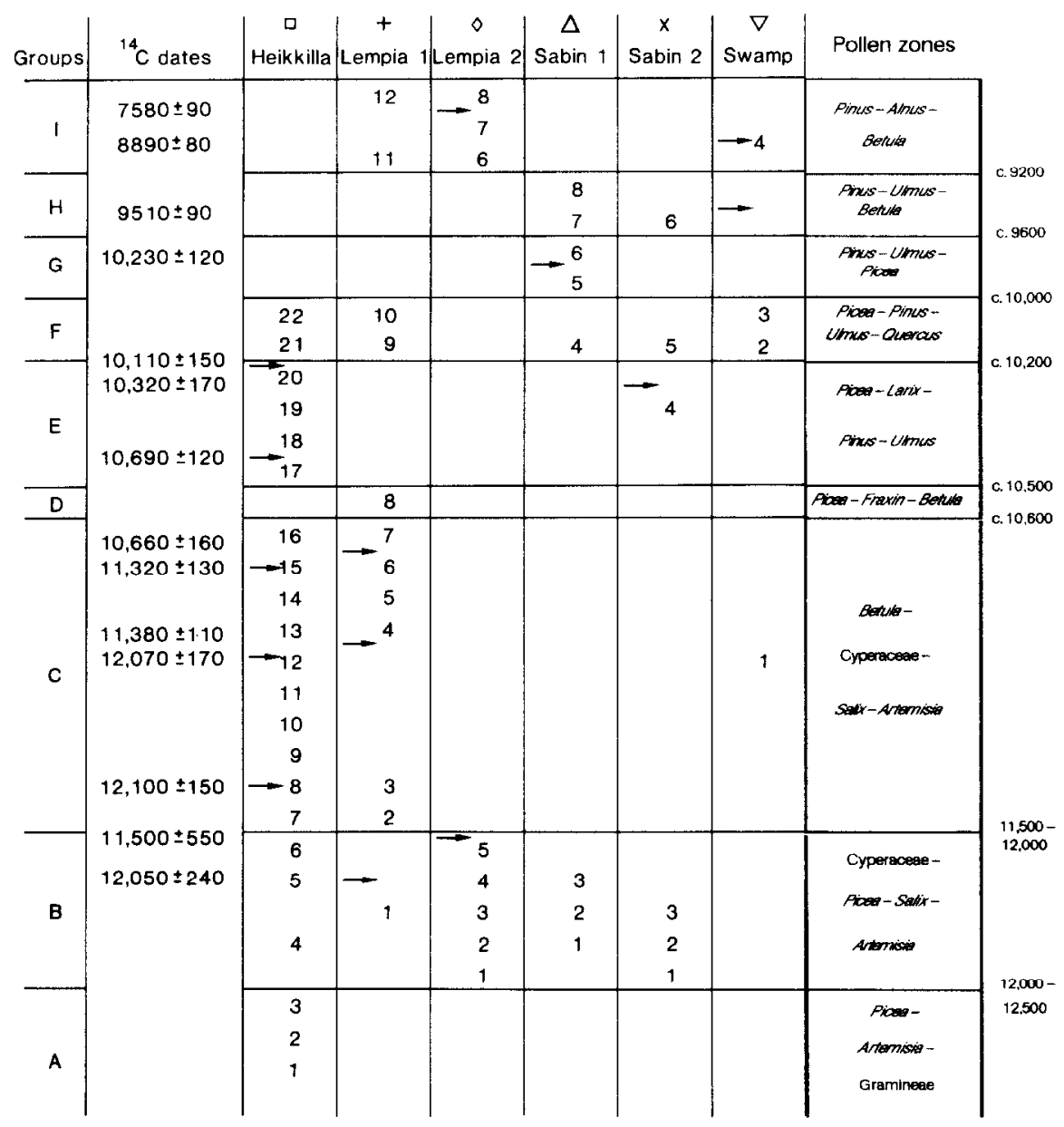

Fig. 9. Stratigraphic layout of the grouping of samples produced by the correspondence analysis. The numbering of samples is the same as in Figure 8, and each radiocarbon-dated level is indicated by an arrow. The assumed age and pollen assemblage of each group are shown to the far right.

sites, the lowest layers (the organic sands of layers 1 and 2 in Table 1) are not interpreted as lacustrine but rather as soil. The sands themselves, however, must have a fluvial, lacustrine, or eolian origin. Layer 3 represents the first real lake $\geqslant 9000$ yr B.P. Prior to this time the Swamp Lake site was characterized by sandy soils. In places these were occasionally flooded, as are the large swampy areas north of the Giants Range today. This indicates a rise of the water table sometime before 9000 yr B.P.

It is clear that lake sediments were formed prior to $12,000-11,500$ yr B.P. (Fig. 9). This period seems to have been followed by $1000-1500$ yr of conditions generally unfavorable for lake sedimentation. Between ca. 10,000 and 9000 yr B.P. more favorable conditions gradually returned. These changing lake-sedimentation conditions can probably be explained in different ways, depending on the types of lake basins.

\section{Heikkilla Lake}

Heikkilla Lake seems to be the only lake with a long and more or less continuous late Wisconsin record. This indicates that the lake basin was completely free of ice rather early, and that the sedimentary environment did not change drastically during the 
time period studied; however, from 12,500 12,000 to at least $10,000 \mathrm{yr}$ B.P. the sedimentation rate gradually decreased.

\section{Lempia Lake}

Layer 4 in Lempia 1 and layer 5 in Lempia 2 resemble what has usually been interpreted as a "trash layer" (Florin and Wright, 1969). They both contain coarse minerogenic matter mixed with coarse organic matter. It is unlikely that these sediments were formed by supraglacial meltout, because they are underlain by well-sorted fine-grained sediments. The sandy, pebbly gyttja clay in Lempia 1 is rather different from layer 5 in Lempia 2, which seems to be a random mixture of coarse matter. This difference is also clearly indicated in Figure 9, which shows a major hiatus at Lempia 2, while layers $4-6$ in Lempia 1 may reflect only disturbed and irregular sedimentation. Because the coarse minerogenic matter is unlikely to have been formed by supraglacial processes, it must have been washed into the basin from the surroundings. It does not, however, exclude the possibility that the lake was occupied by ice when the sediments were deposited. On the contrary, layers 1-3 and 1-4 could have been deposited in a lake on top of stagnant ice. If this is the case the hiatus in Lempia 2 and the irregular sedimentation in Lempia 1 might indicate a water-level lowering followed by a rather substantial rise (layers 5 and 6, respectively).

\section{Sabin Lake}

The hiatuses in the stratigraphy of Sabin 1 and Sabin 2 (Fig. 9) are both related to layers $5.5-6.0 \mathrm{~cm}$ thick that are rich in coarse minerogenic matter and occur at the same water depth. The only difference between layer 3 in Sabin 1 and layer 2 in Sabin 2 is that the pollen spectra of the very coarse layer in Sabin 1 places it in phase F, while the finer layer in Sabin 2 is placed in group B (Fig. 9, samples 4 and 3, respectively). Layer 3 (sample 4) in Sabin 1 may be contaminated by pollen and some fine minerogenic particles from the much finer layer 4 above to the sandy pebbly layer 3 . By this interpretation of the pollenstratigraphic anomaly, the hiatus in Sabin Lake dates from $>11,500$ to ca. $10,200 \mathrm{yr}$ B.P. Because this lake is part of the Embarrass River it is not likely that these changing sediments and significant hiatuses were caused by local lake-level changes, but rather by changing drainage patterns. Examples of such changes are the damming of the area north of the Giants Range by the St. Louis Sublobe or changes in the drainage of Lake Koochiching (Hobbs, 1983).

\section{Swamp Lake}

In comparison with the other lakes, the stratigraphy at Swamp Lake is harder to interpret with respect to water-level changes. The corings were made on the peaty shore so only the underlying sands (with pollen) and the onset of lake-marginal sedimentation (with pollen and ${ }^{14} \mathrm{C}$ ) could be dated. The sands were deposited between ca. 11,500 or 11,000 and 10,000 or $9500 \mathrm{yr}$ B.P., followed by the beginning of near-shore sedimentation $9500-9000 \mathrm{yr}$ B.P.

\section{Synthesis from the "Hiatus" Stratigraphy}

The causes for hiatuses may vary from lake to lake. The timing, however, corresponds very well. Together with the reconstructed glacial history and chronology of the region this indicates that the hiatuses have a common genesis.

When the southern sublobe of the St. Louis Sublobe entered the region sometime before 11,500 yr B.P., it partly filled the Embarrass channel and partly dammed the relatively flat area north of the Giants Range. This created Glacial Lake Norwood, in which sand, silt, and clay were deposited. During this possibly brief time, layer 1 (samples 1-6) in Heikkilla Lake, layers 1-3 (samples 1-3) in Lempia Lake 1, layers 1-3 (samples 1-4) in Lempia Lake 2, layers 1-2 (samples 1-3) in Sabin Lake 1, 
and layers 1-2 (samples 1-3) in Sabin Lake 2 are inferred to have been deposited.

Because the sediments are not reddish (as are the clays of Glacial Lake Upham and the tills of the St. Louis Sublobe), the main sediment source must have been meltwater from active and stagnant ice of the Rainy Lobe. This phase corresponds to Glacial Lake Norwood, which must have reached an altitude of at least $448 \mathrm{~m}$ (1470 $\mathrm{ft}$ ) at the threshold of Lempia Lake. This is also the approximate upper limit of sands and silts in the area. The threshold area southeast of Lempia Lake is connected with the low-lying areas of the Embarrass River through Bear Creek. All other basins studied are situated well below $448 \mathrm{~m}$. This also implies that the St. Louis Sublobe reached at most halfway into the Embarrass channel from the south, i.e., Wynne Lake. Because the till of this lobe is not found in the channel, but just south of it at Biwalbik and Aurora (Winter, 1973), the ice must have blocked only the southern exit of that valley.

When the St. Louis Sublobe retreated from the Embarrass channel the glacial lake was drained to the south, and the lake level dropped tens of meters. In Lempia Lake the supraglacial glaciolacustrine sediments were exposed, and coarse organic and minerogenic matter was washed onto the sediment-covered stagnant ice from surrounding ice blocks or unstable soils. In Sabin Lake the flow through the Embarrass channel was of such magnitude that sediments were eroded, especially the finer sediments of Glacial Lake Norwood. This flow must have increased significantly if and when Lake Koochiching was drained by the Embarrass River (Hobbs, 1983). During this time, with the melting of stagnant ice and also the draining of parts of Glacial Lake Agassiz, Sabin Lake acted more like a river than a lake, which prevented normal lake sedimentation. In Heikkilla Lake nothing dramatic happened. The lake became isolated and the organic content of the sediments gradually increased. At Swamp Lake the former glacial lake bed became dry and subject to weathering.

The next event in the "hiatus" stratigraphy also seems to have occurred almost simultaneously (Fig. 9). Normal sedimentation began ca. 10,200 yr B.P. in all the lakes studied. This is interpreted as the end of melting of stagnant ice and the onset of more normal conditions for lacustrine sedimentation in kettle lakes like Lempia Lake. Water flow in the Embarrass channel decreased as the meltwater input ceased, creating conditions more favorable for lacustrine sedimentation in Sabin Lake. Sometime between 9500 and 9000 yr B.P., the low-lying sandy, silty areas, such as those surrounding Swamp Lake, became paludified and overgrown by peat. This may have been caused by a rising water table.

\section{CONCLUDING REMARKS}

The original aim of these studies was to identify any climatic or other environmental changes that might be related to the lateglacial advance of the St. Louis Sublobe. Because of its extreme proximity to this ice lobe, the study area ought to be ideal for that purpose. However, the oldest sediments in Heikkilla Lake, or in any of the other lakes, probably do not date from the onset of this advancce, but rather are contemporaneous with its culmination. Thus the pollen stratigraphy possibly does not reveal any major climatic cooling that could be related to the ice readvance. Neither is any significant and sudden warming, related to the retreat of this lobe, noted in the pollen stratigraphy. Had only the Heikkilla Lake record been studied, it would have shown a gradual revegetation of the area with an unusually long birch phase. In this case, when many different basins were studied and the stratigraphy of Heikkilla Lake was assumed to be more or less complete, the pollen stratigraphy of this lake could function as a standard stratigraphy against which the other stratigraphies could be compared numerically. The basic pre- 
requisite for such a comparison is the assumption that the late Wisconsin vegetation history was fairly uniform within the small study area. Correspondence analysis of the entire data set reveals significant hiatuses in all but Heikkilla Lake (however, small, undetected, and thus insignificant hiatuses could also exist in Heikkiilla Lake).

The dated hiatuses and clear lithologic changes can be correlated with regionally important events, such as (1) the advance and retreat of the St. Louis Sublobe to create and drain Glacial Lake Norwood north of the Giants Range, (2) the drainage of Lake Koochiching through the Embarrass channel, and (3) the final melting of stagnant ice within the study area.

These events can be detected, however, not by traditional investigations of a single sediment core, but rather with a combination of litho- and biostratigraphy, chronology, and appropriate multivariate numerical techniques. Only through these approaches were the complex "hiatus" stratigraphies detected and related to significant events in the late Wisconsin history of the study area.

\section{ACKNOWLEDGMENTS}

Howard Mooers introduced me to the study area; George King, Geoffrey Seltzer, and Herbert Wright, Jr., assisted me with the corings; Christin Andréasson drafted most of the figures; Doris Persson prepared the pollen samples; and George Jacobson, Jr., and Herbert Wright, Jr., critically read the manuscript and checked the English. Discussions with those two as well as with John Birks have been of great value. To all these persons I am very grateful. I also thank the referees (E. Cushing and D. Mickelson) for their detailed examination of the study and their valuable and constructive viewpoints. The study was partially financed by The Swedish Natural Science Research Council (NFR) and the U.S. National Science Foundation, which are gratefully acknowledged.

\section{REFERENCES}

Amundson, D. C., and Wright, H. E., Jr. (1979). Forest changes in Minnesota at the end of the Pleistocene. Ecological Monographs, 1979, 1-16.

Birks, H. J. B. (1976). Late-Wisconsinan vegetational history at Wolf Creek, central Minnesota. Ecological Monographs 46, 395-429.
Birks, H. J. B. (1981). Late Wisconsinan vegetational and climatic history at Kylen Lake, northeastern Minnesota. Quaternary Research 16, 60-86.

Björck, S. (1985). Deglaciation chronology and revegetation in northwestern Ontario. Canadian Journal of Earth Sciences 22, 850-871.

Björck, S., and Håkansson, S. (1982). Radiocarbon dates from Late Weichselian lake sediments in South Sweden as a basis for chronostratigraphic subdivision. Boreas 11, 141-150.

Björck, S., Persson, T., and Kristersson, I. (1978). Comparison of two concentration methods for pollen in minerogenic sediments. Geologiska Föreningens $i$ Stockholm Förhandlingar 100, 107-111.

Clayton, L. (1983). Chronology of Lake Agassiz drainage to Lake Superior. In "Glacial Lake Agassiz" (J. T. Teller and Lee Cayton Eds.), Geological Association of Canada Special Paper 26, pp 291-307.

Clayton, L., and Moran, S. R. (1982). Chronology of Late Wisconsinan glaciation in Middle North America. Quaternary Science Review 1, 55-82.

Craig, A. J. (1972). Pollen influx to laminated sediments: A pollen diagram from northeastern Minnesota. Ecology 53, 46-57.

Cushing, E. J. (1967). Late-Wisconsin pollen stratigraphy and the glacial sequence in Minnesota. In "Quaternary Paleoecology" (E. J. Cushing and H. E. Wright, Jr., Eds.). pp. 59-88. Yale Univ. Press, New Haven, CT.

Faegri, K., and Iversen, J. (1975). "Textbook of Pollen Analysis," 3rd ed. Blackwell Scientific, Oxford.

Florin, M.-B., and Wright, H. E., Jr. (1969). Diatom evidence for the persistence of stagnant glacial ice in Minnesota. Geological Society of America Bulletin 80, 695-704.

Fries, M. (1962). Pollen profiles of Late Pleistocene and Recent sediments from Weber Lake, Minnesota. Ecology 43, 295-308.

Greenacre, M. J. (1984). Practical correspondence analysis. In "Interpreting Multivariate Data" (V. Barnett, Ed.), pp. 119-146. Wiley, New York.

Hill, M. O. (1974). Correspondence analysis: A neglected multivariate method. Applied Statistics 23, 340-354.

Hobbs, H. C. (1983). Drainage relationships of Glacial Lakes Aitkin and Upham and early Lake Agassiz in northastern Minnesota. In "Glacial Lake Agassiz" (J. T. Teller and Lee Clayton, Eds.). Geological Association of Canada Special Paper 26, pp. 245-259.

Jacobson, G. L., Jr., Webb, T., III, and Grimm, E. C. (1987). Patterns and rates of vegetation change during the deglaciation of eastern North America. In "Geology of North America." Vol. K-3. "North America and Adjacent Oceans during the Last Deglaciation"' (W. R. Ruddiman and H. E. Wright, Jr., Eds.), pp. 277-288. Geological Society of America, Boulder, CO.

Stockmarr, J. (1971). Tablets with spores used in ab- 
solute pollen analysis. Pollen et Spores 13, 615-621.

Winchell, N. H. (1901). Glacial lakes of Minnesota. Geological Society of America Bulletin 12, 109-128.

Winter, T. C. (1971). "Sequence of Glaciation in the Mesabi-Vermillion Iron Range Area, Northeastern Minnesota." U.S. Geological Survey Professional Paper 750-C, pp. C82-C88.

Winter, T. C. (1973). "Hydrogeology of Glacial Drift, Mesabi Range, Northeastern Minnesota." U.S. Geological Survey Water-Supply Paper 2029-A, pp. A1-A23.

Winter, T. C., Cotter, R. D., and Young, H. L. (1973). "Petrography and Stratigraphy of Glacial Drift, Mesabi-Vermilion Iron Range Area, Northeastern Minnesota." U.S. Geological Survey Bulletin 1331-C, pp. C1-C41.

Wright, H. E., Jr. (1967). A square-rod piston sampler for lake sediments. Journal of Sedimentary Petrology 37, 975-976.

Wright, H. E., Jr. (1969). Glacial fluctuations and the forest succession in the Lake Superior area. In "Proceedings of the 12th Conference on Great Lakes Research 1969," pp. 397-405.

Wright, H. E., Jr. (1972). Quaternary history of Minnesota. In "Geology of Minnesota" (P. K. Sims and G. B. Morey, Eds.), pp. 515-548. Minnesota Geological Survey.

Wright, H. E., Jr. (1973). Tunnel valleys, glacial surges, and subglacial hydrology of the Superior Lobe, Minnesota. Geological Society of America Memoir 136, 251-276.

Wright, H. E., Jr., and Watts, W. A. (1969). "Glacial and Vegetational History of Northeastern Minnesota," Special Publication Series SP-11, pp. 1-59. Minnesota Geological Survey.

Wright, H. E., Jr., Winter, T. C., and Patten, H. L. (1963). Two pollen diagrams from southeastern Minnesota: Problems in the late and postglacial vegetational history. Geological Society of America Bulle$\operatorname{tin} 74,1371-1396$. 